\title{
Article
}

\section{Structural and Electrochemical Studies of Cobalt(II) and Nickel(II) Coordination Polymers with 6-Oxonicotinate and 4,4'-Bipyridine}

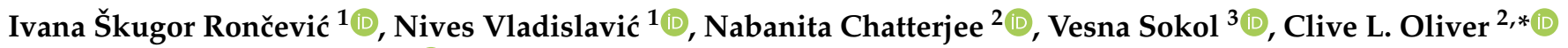 \\ and Boris-Marko Kukovec ${ }^{3, * \text { (D) }}$ \\ 1 Department of General and Inorganic Chemistry, Faculty of Chemistry and Technology, University of Split, \\ Ruđera Boškovića 35, 21000 Split, Croatia; skugor@ktf-split.hr (I.Š.R.); nives@ktf-split.hr (N.V.) \\ 2 Department of Chemistry, University of Cape Town, Rondebosch 7701, South Africa; \\ nabanita.chem@gmail.com \\ 3 Department of Physical Chemistry, Faculty of Chemistry and Technology, University of Split, \\ Ruđera Boškovića 35, 21000 Split, Croatia; vsokol@ktf-split.hr \\ * Correspondence: clive.oliver@uct.ac.za (C.L.O.); bmkukovec@ktf-split.hr (B.-M.K.)
}

check for updates

Citation: Škugor Rončević, I.; Vladislavić, N.; Chatterjee, N.; Sokol,

V.; Oliver, C.L.; Kukovec, B.-M. Structural and Electrochemical Studies of Cobalt(II) and Nickel(II) Coordination Polymers with 6-Oxonicotinate and 4,4'-Bipyridine. Chemosensors 2021, 9, 352. https:// doi.org/10.3390/chemosensors9120352

Academic Editor: Győző G. Láng

Received: 15 November 2021 Accepted: 3 December 2021 Published: 10 December 2021

Publisher's Note: MDPI stays neutral with regard to jurisdictional claims in published maps and institutional affiliations.

Copyright: (c) 2021 by the authors. Licensee MDPI, Basel, Switzerland. This article is an open access article distributed under the terms and conditions of the Creative Commons Attribution (CC BY) license (https:/ / creativecommons.org/licenses/by/ $4.0 /)$.

\begin{abstract}
The 6-oxonicotinate (6-Onic) salts of a one-dimensional cationic cobalt(II) or nickel(II) coordination polymers with $4,4^{\prime}$-bipyridine $\left(4,4^{\prime}\right.$-bpy), namely $\left\{\left[\mathrm{Co}\left(4,4^{\prime} \text {-bpy }\right)\left(\mathrm{H}_{2} \mathrm{O}\right)_{4}\right](6-\mathrm{O} \text {-Onic })_{2} \cdot 2 \mathrm{H}_{2} \mathrm{O}\right\}_{n}$ (1) and $\left\{\left[\mathrm{Ni}\left(4,4^{\prime} \text {-bpy) }\left(\mathrm{H}_{2} \mathrm{O}\right)_{4}\right](6-\mathrm{Onic})_{2} \cdot 2 \mathrm{H}_{2} \mathrm{O}\right\}_{n}\right.$ (2), were prepared hydrothermally by reactions of cobalt(II) nitrate hexahydrate or nickel(II) nitrate hexahydrate, respectively, 6-hydroxynicotinic acid and 4,4'-bipyridine in a mixture of ethanol and water. In the hydrogen-bonded frameworks of 1 and 2, the one-dimensional polymeric chains of $\left\{\left[\mathrm{M}\left(4,4^{\prime}-\text { bpy }\right)\left(\mathrm{H}_{2} \mathrm{O}\right)_{4}\right]^{2+}\right\}_{n}(\mathrm{M}=\mathrm{Co}, \mathrm{Ni})$, the 6-oxonicotinate anions and the lattice water molecules were assembled via strong intermolecular $\mathrm{O}-\mathrm{H} \cdots \mathrm{O}$ and $\mathrm{N}-\mathrm{H} \cdots \mathrm{O}$ hydrogen bonds and $\pi-\pi$ interactions, leading to the formation of the representative hydrogen-bond ring motifs: trimeric $R^{2}{ }_{3}(10)$ motif, the centrosymmetric tetrameric $R^{2}{ }_{4}(8)$ and $R^{2}{ }_{4}(12)$ motifs and the pentameric $R^{4}{ }_{5}(12)$ motif. The isostructural coordination polymers 1 and 2 exhibited a different electrochemical behavior, as observed by cyclic voltammetry, which can be attributed to the nature of the metal ions (cobalt(II) vs. nickel(II)).
\end{abstract}

Keywords: coordination polymers; cobalt(II); nickel(II); 6-hydroxynicotinate; 4,4'-bipyridine; hydrogen-bond motifs; cyclic voltammetry

\section{Introduction}

The design of coordination polymers has become an important field of crystal engineering due to their various functional properties and many possible applications, e.g., in catalysis, gas and energy storage, gas separation, magnetism, luminescence, molecular sensing, biomedical imaging [1-8]. The coordination preferences of the particular metal ions and the respective geometric and electronic properties of the ligands have been extensively studied in the past, but are still not understood completely. Furthermore, the supramolecular assembling of coordination polymers employing weak interactions (hydrogen bonds, halogen bonds, $\pi-\pi$ interactions) is also less predictable, but gains more and more attention, in the hope to shed light on the control of these weak interactions in the formation of coordination polymers with the desired frameworks and properties.

By properly selecting experimental parameters such as a choice of solvents, starting metal salts, additional ligands, temperature, hydrothermal conditions, $\mathrm{pH}$ value of the reaction mixture etc., it is possible to optimize the design of the desired coordination polymers, and thus control the outcome of the crystallization experiments [9-12]. However, the preparation and crystallization of coordination polymers still remain very challenging.

The electrochemical properties of coordination polymers have been neglected in the past, but are attracting more interest as of recently. Cyclic voltammetry is the most 
frequently used electrochemical technique in the characterization of coordination polymers, whether providing information on redox activity $[13,14]$ of the respective metal ions and ligands, or is simply used to elucidate the electrochemical sensor properties $[15,16]$ of coordination polymers, e.g., as an electrode surface modifier because of their potential to undergo reversible single-electron processes which enable them to sense many analytes, e.g., anions [17,18], cations [19,20] or organic compounds [21]. The electrochemical sensing ability of coordination polymers is generally affected by the type of the corresponding metal ions and functional organic ligands. For instance, cobalt(II) coordination polymers are considered to be promising candidates for electrochemical sensing because of their low cost, high accessibility and great electrocatalytic performance [22]. On the other hand, organic ligands in coordination polymers contribute significantly to their electrochemical sensing potential, also enhancing their electron conduction rate [23].

We have prepared two structurally different $1 \mathrm{D}$ cobalt(II) coordination polymers with bromine and chlorine halosubstituents: $\left\{\left[\mathrm{Co}(2-\mathrm{Clnic})_{2}\left(4,4^{\prime}-\mathrm{bpy}\right)\left(\mathrm{H}_{2} \mathrm{O}\right)_{2}\right] \cdot 4 \mathrm{H}_{2} \mathrm{O}\right\}_{n}$ and $\left\{\left[\mathrm{Co}\left(4,4^{\prime} \text {-bpy }\right)\left(\mathrm{H}_{2} \mathrm{O}\right)_{4}\right]\left[\mathrm{Co}(5-\mathrm{Brnic})_{4}\left(\mathrm{H}_{2} \mathrm{O}\right)_{2}\right] \cdot 4,4^{\prime} \text {-bpy } 2 \mathrm{H}_{2} \mathrm{O}\right\}_{n}$. Using DFT calculations, the influence of the type and position of halosubstituents in the pyridine ring of nicotinate ligands was deciphered. Their position results in different structural types of coordination polymers. These structural differences should be ascribed solely to the different positions of the introduced halogen atoms in the pyridine ring of the ligands and not to the types of the halogen atoms [24]. Similar nickel(II) coordination polymers were prepared in the same way, with fluorine and chlorine halosubstituents: $\left\{\left[\mathrm{Ni}(6-\mathrm{Fnic})_{2}\left(4,4^{\prime}\right.\right.\right.$ bpy) $\left.\left.\left(\mathrm{H}_{2} \mathrm{O}\right)_{2}\right] \cdot 3 \mathrm{H}_{2} \mathrm{O}\right\}_{n}[25]$ and $\left\{\left[\mathrm{Ni}\left(4,4^{\prime} \text {-bpy }\right)\left(\mathrm{H}_{2} \mathrm{O}\right)_{4}\right](6-\mathrm{Clnic})_{2} \cdot 4 \mathrm{H}_{2} \mathrm{O}\right\}_{n}$ [26]. Although being prepared under the same experimental conditions, two different types of 1D coordination polymers were obtained. The fluorine coordination polymer resembles the analogous chlorine cobalt(II) coordination polymer, while chlorine nickel(II) polymer consists of a complex cation $\left\{\left[\mathrm{Ni}\left(4,4^{\prime} \text {-bpy }\right)\left(\mathrm{H}_{2} \mathrm{O}\right)_{4}\right]^{2+}\right\}_{n}$ and non-coordinated 6-chloronicotinate anions. Since all experimental parameters remained unchanged, these structural differences in the nickel(II) coordination polymers should be probably attributed to the type of halosubstituents (fluorine and chlorine) in the nicotinate ligands used [25,26].

Our current motivation was to further explore whether the introduction of substituents, other than the halide atoms, e.g., hydroxyl, in the specific position (-6) in the aromatic ring of the nicotinate ligands (6-hydroxynicotinate (6-OHnic) as opposed to 6-fluoronicotinate and 6-chloronicotinate) has any effect on the coordination environments of the metal ions and, consecutively, on the structural types of the obtained 1D coordination polymers. In order to ensure this, we again used well-established cobalt(II) and nickel(II) ions (with similar ionic radii, but different electronic configurations) and 4,4'-bipyridine linker to enable the formation of the analogous 1D polymers. Since the halosubstituents in the nicotinate ligands are now replaced by hydroxyl substituent, which have far greater potential in hydrogen-bonding than halosubstituents, we were particularly interested to check the differences in the formed hydrogen-bonded frameworks, with a special attention on the hydrogen-bond motifs within, which might arise from an enhanced participation of hydroxyl substituent in hydrogen bonding.

In this report, we prepared two isostructural 1D cobalt(II) and nickel coordination polymers with $4,4^{\prime}$-bipyridine $\left(4,4^{\prime}\right.$-bpy) and 6-oxonicotinate (6-Onic), namely $\left\{\left[\mathrm{Co}\left(4,4^{\prime}\right.\right.\right.$ bpy) $\left.\left.\left(\mathrm{H}_{2} \mathrm{O}\right)_{4}\right](6-\mathrm{Onic})_{2} \cdot 2 \mathrm{H}_{2} \mathrm{O}\right\}_{n}(\mathbf{1})$ and $\left\{\left[\mathrm{Ni}\left(4,4^{\prime}-\mathrm{bpy}\right)\left(\mathrm{H}_{2} \mathrm{O}\right)_{4}\right](6-\mathrm{Onic})_{2} \cdot 2 \mathrm{H}_{2} \mathrm{O}\right\}_{n}$ (2). Voltammetric studies on these two polymers were carried out to explore their different electrochemical properties and to determine the origin of these electrochemical differences in this isostructural system.

\section{Materials and Methods}

\subsection{Materials and Physical Measurements}

The chemicals and materials were commercially available, of reagent purity and used as received without further purification. 
A Carlo Erba microanalyzer at the Microanalytical Laboratory of the University of Vienna, Austria, was used to perform CHNO elemental analyses.

IR spectra (KBr pellets) were collected on a Shimadzu IRAffinity-1 FT-IR spectrometer in a range of $4000-400 \mathrm{~cm}^{-1}$.

TGA/DTA curves were recorded on a Shimadzu DTG-60H analyzer (from room temperature (RT) to $800^{\circ} \mathrm{C}$ ) in a stream of synthetic air and by applying a heating rate of $10{ }^{\circ} \mathrm{C} \min ^{-1}$.

\subsection{Preparation of Coordination Polymers 1 and 2}

6-Hydroxynicotinic acid $(0.050 \mathrm{~g}, 0.358 \mathrm{mmol})$ was dissolved in $4 \mathrm{~mL}$ of distilled water, 4, $4^{\prime}$-bipyridine $(0.028 \mathrm{~g}, 0.179 \mathrm{mmol}$ ) was dissolved in $2 \mathrm{~mL}$ of ethanol and cobalt(II) (for 1) or nickel(II) (for 2$)$ nitrate hexahydrate $(0.052 \mathrm{~g}, 0.179 \mathrm{mmol})$ was dissolved in $2 \mathrm{~mL}$ of distilled water. The solutions of the two ligands were first mixed together under stirring. The resulting solutions was then slowly added to the cobalt(II) (for 1) or nickel(II) nitrate (for 2) solutions under stirring. The $\mathrm{pH}$ of the final solutions was adjusted to 7 by adding a sodium hydroxide solution dropwise. The reaction mixtures were heated in the Teflon lined autoclave for 3 days at $130{ }^{\circ} \mathrm{C}$ and then left to cool slowly to the room temperature over 1 day.

The pink precipitate of $\mathbf{1}$ and the green precipitate of $\mathbf{2}$ were obtained, collected by filtration, washed with water and dried in a desiccator over $\mathrm{CaCl}_{2}$. Yield of 1: $0.0376 \mathrm{~g}$ (35\%). Yield of 2: $0.0231 \mathrm{~g}(21 \%)$.

The clear solutions, remained after filtration, were left to evaporate slowly at room temperature until pink crystals of $\mathbf{1}$ and green crystals of $\mathbf{2}$, suitable for X-ray diffraction measurements, were obtained. It took approximately two days for the crystals of $\mathbf{1}$ and seven days for the crystals of 2 .

(1): $0.0283 \mathrm{~g}(26 \%)$. Anal. calc. for $\mathrm{C}_{22} \mathrm{H}_{28} \mathrm{CoN}_{4} \mathrm{O}_{12}\left(M_{\mathrm{r}}=599.41\right): \mathrm{C}, 44.08 ; \mathrm{H}, 4.71$; $\mathrm{N}, 9.35 ; \mathrm{O}, 32.03 \%$. Found: C, 43.91; H, 4.73; N, 9.32; O, 33.34\%. IR $\left(\mathrm{KBr}, \mathrm{cm}^{-1}\right)$ : 3549-3415 (m) [v(O-H)], $3234(\mathrm{w}), 2367(\mathrm{w}), 2028(\mathrm{w}), 1643(\mathrm{~s})$ and $1618(\mathrm{~s})\left[v_{\mathrm{as}}\left(\mathrm{COO}^{-}\right)\right]$, $1562(\mathrm{~m}), 1530(\mathrm{~m}), 1473(\mathrm{w}), 1422(\mathrm{~m}), 1382(\mathrm{~s})\left[v_{\mathrm{s}}\left(\mathrm{COO}^{-}\right)\right], 1217(\mathrm{~m}), 1132(\mathrm{w}), 1067(\mathrm{w})$, $1030(\mathrm{w}), 986(\mathrm{w}), 941(\mathrm{w}), 802(\mathrm{~m}), 733(\mathrm{w}), 637(\mathrm{~m}), 497(\mathrm{w}), 469(\mathrm{w}), 401(\mathrm{w})$ (Figure S1 in the Supplementary Materials).

(2): $0.0273 \mathrm{~g}(25 \%)$. Anal. calc. for $\mathrm{C}_{22} \mathrm{H}_{28} \mathrm{NiN}_{4} \mathrm{O}_{12}\left(M_{\mathrm{r}}=599.19\right): \mathrm{C}, 44.07 ; \mathrm{H}, 4.71$; $\mathrm{N}, 9.33 ; \mathrm{O}, 32.04 \%$. Found: C, 43.81; H, 4.69; N, 9.33; O, 31.34\%. IR $\left(\mathrm{KBr}, \mathrm{cm}^{-1}\right): 3413(\mathrm{~m})$ $[v(\mathrm{O}-\mathrm{H})], 2035(\mathrm{w}), 1870(\mathrm{w}), 1643(\mathrm{~s})$ and $1618(\mathrm{~s})\left[v_{\mathrm{as}}\left(\mathrm{COO}^{-}\right)\right], 1562(\mathrm{~m}), 1532(\mathrm{~m}), 1476(\mathrm{w})$, $1420(\mathrm{~m}), 1382(\mathrm{~s})\left[v_{\mathrm{s}}\left(\mathrm{COO}^{-}\right)\right], 1220(\mathrm{~m}), 1134(\mathrm{w}), 1067(\mathrm{w}), 1031(\mathrm{w}), 986(\mathrm{w}), 943(\mathrm{w}), 802(\mathrm{~m})$, $733(\mathrm{w}), 636(\mathrm{~m}), 528(\mathrm{w}), 500(\mathrm{w}), 470(\mathrm{w})$ (Figure S2 in the Supplementary Materials).

The CHNO analyses and IR spectroscopy were used to confirm that the precipitates and the crystals are the same compounds, in case of both $\mathbf{1}$ or $\mathbf{2}$.

\subsection{Electrochemical Measurements}

Preparation of MWCNT suspension $\left(\gamma=0.5 \mathrm{mg} \mathrm{mL}^{-1} ; V=10 \mathrm{~mL}\right): 5 \mathrm{mg}$ of MWCNT was added to $10 \mathrm{~mL}$ of $\mathrm{N}, \mathrm{N}$-dimethylformamide (DMF), and the mixture was treated in an ultrasonic bath for $10 \mathrm{~h}$ to obtain a homogeneous suspension.

Preparation of MWCNT | 1(2) suspension $\left(\gamma=0.5 \mathrm{mg} \mathrm{mL}^{-1} ; V=10 \mathrm{~mL}\right): 5 \mathrm{mg}$ of MWCNT and $5 \mathrm{mg}$ of coordination polymers 1 or 2 was added to $10 \mathrm{~mL}$ of $\mathrm{N}, \mathrm{N}$ dimethylformamide (DMF), and the mixture was treated in an ultrasonic bath for $10 \mathrm{~h}$ to obtain a homogeneous suspension.

The working electrode was glassy carbon (GC) electrode (electrode diameter $5 \mathrm{~mm}$ ), modified with a suspension of multi-walled carbon nanotubes (MWCNT) and prepared polymers 1 and 2. Prior modification, GC electrode was polished with alumina powder (1 and $0.05 \mu \mathrm{m})$ and rinsed with distilled water. A homogeneous suspension $(15 \mu \mathrm{L})$ was transferred dropwise to the GC surface and dried in an oven for $30 \mathrm{~min}$ at a temperature of $50{ }^{\circ} \mathrm{C}$. 
All electrochemical experiments were performed in a standard three-electrode cell (Pt-counter electrode and $\mathrm{Ag} \mid \mathrm{AgCl}$, with $3.0 \mathrm{~mol} \mathrm{dm}^{-3} \mathrm{KCl}$, as a reference electrode). Cyclic voltammograms were carried out using a potentiostat (Autolab PGSTAT 302N), connected to a PC and GPES 4.9 Software (Eco Chemie). EIS measurements were carried out using a Solartron SI 1287 electrochemical interface and a Solartron SI 1255 frequency response analyzer controlled by a personal computer.

Cyclic voltammograms were recorded in a broader range from -1.0 to $1.2 \mathrm{~V} \mathrm{vs.} \mathrm{Ag} / \mathrm{AgCl}$, with a scan rate of $50 \mathrm{mV} \mathrm{s}^{-1}$ at MWCNT electrode, MWCNT | 1 electrode and MWCNT $\mid 2$ electrode in $0.1 \mathrm{~mol} \mathrm{~L}^{-1} \mathrm{KNO}_{3}$ solution, $\mathrm{pH} 7.0$ (Figure S3 in the Supplementary Materials). EIS measurements were performed at the open circuit potential $\left(E_{\mathrm{OCP}}\right)$ over the frequency range $100 \mathrm{kHz}$ to $10 \mathrm{mHz}$ and $5 \mathrm{mV}$ amplitude. Nyquist plots were fitted using the Randles modified equivalent circuit, deduced by using complex non-linear least squares (Figure S4 in the Supplementary Materials).

\subsection{X-ray Crystallographic Analysis}

The suitable single crystals of $\mathbf{1}$ and $\mathbf{2}$ were selected and mounted in Paratone-N oil onto cryoloops. The Bruker D8 Venture diffractometer producing $\operatorname{MoK} \alpha(\lambda=0.71073 \AA)$ radiation at $50 \mathrm{kV}$ and $1.4 \mathrm{~mA}$, with the crystal cooled with an Oxford Cryostream $800(100(2) \mathrm{K})$, was used for data collection. The cell refinement and data reduction were performed using SAINT [27]. The X-ray diffraction data have been corrected for Lorentzpolarization factor and scaled for absorption effects by multi-scan using SADABS [28]. The crystal structures were solved by SHELXT [29] and refined by SHELXL-2018/3 [30]. The refinement procedure was obtained by full-matrix least-squares methods based on $F^{2}$ values against all reflections. The $\mathrm{C} 1$ and $\mathrm{C} 2$ atoms in polymers $\mathbf{1}$ and $\mathbf{2}$ were disordered and refined in two positions, resulting with site occupancy factors of 0.502(8) for 1 and 0.508 (8) for 2 . These values exhibit virtually 50:50 ratio of the disorder components of those atoms (all figures show only one component of the disordered atoms, C1A and C2A). The $\mathrm{C}-\mathrm{N}$ and $\mathrm{C}-\mathrm{C}$ distances around the disordered atoms were refined freely. The figures were made with MERCURY (Version 2020.2.0) [31]. The crystallographic data for $\mathbf{1}$ and $\mathbf{2}$ are shown in Table 1.

Table 1. The crystallographic data for $\left\{\left[\mathrm{Co}\left(4,4^{\prime}-\mathrm{bpy}\right)\left(\mathrm{H}_{2} \mathrm{O}\right)_{4}\right](6-\mathrm{OHnic})_{2} \cdot 2 \mathrm{H}_{2} \mathrm{O}\right\}_{n}$ (1) and $\left\{\left[\mathrm{Ni}\left(4,4^{\prime}-\mathrm{bpy}\right)\left(\mathrm{H}_{2} \mathrm{O}\right)_{4}\right](6-\right.$ Onic) $\left.)_{2} \cdot 2 \mathrm{H}_{2} \mathrm{O}\right\}_{n}(2)$.

\begin{tabular}{|c|c|c|}
\hline Compound & 1 & 2 \\
\hline Formula & $\left\{\left[\mathrm{C}_{10} \mathrm{H}_{16} \mathrm{CoN}_{2} \mathrm{O}_{4}\right]\left(\mathrm{C}_{6} \mathrm{H}_{4} \mathrm{NO}_{3}\right)_{2} \cdot 2 \mathrm{H}_{2} \mathrm{O}\right\}_{n}$ & $\left\{\left[\mathrm{C}_{10} \mathrm{H}_{16} \mathrm{NiN}_{2} \mathrm{O}_{4}\right]\left(\mathrm{C}_{6} \mathrm{H}_{4} \mathrm{NO}_{3}\right)_{2} \cdot 2 \mathrm{H}_{2} \mathrm{O}\right\}_{n}$ \\
\hline$M_{\mathrm{r}}$ & 599.41 & 599.19 \\
\hline Crystal system, space group & $\begin{array}{c}\text { monoclinic, } C 2 / c \\
\text { (No. 15) }\end{array}$ & $\begin{array}{c}\text { monoclinic, } C 2 / c \\
(\text { No. } 15)\end{array}$ \\
\hline$a(\AA)$ & $19.0114(13)$ & $18.9891(9)$ \\
\hline$b(\AA)$ & $11.4133(7)$ & $11.3111(5)$ \\
\hline$c(\AA)$ & $12.0374(7)$ & $12.0639(6)$ \\
\hline$\beta\left(^{\circ}\right)$ & $99.333(2)$ & $99.169(2)$ \\
\hline$V\left(\AA^{3}\right)$ & 2577.3(3) & $2558.1(2)$ \\
\hline Z & 4 & 4 \\
\hline$D_{\text {calc }}\left(\mathrm{g} \mathrm{cm}^{-3}\right)$ & 1.545 & 1.556 \\
\hline$\mu\left(\mathrm{mm}^{-1}\right)$ & 0.737 & 0.830 \\
\hline$R[I \geq 2 \sigma(I)]$ & 0.0480 & 0.0473 \\
\hline $\mathrm{w} R$ [all data] & 0.1260 & 0.1228 \\
\hline
\end{tabular}

\section{Results and Discussion}

\subsection{Syntheses}

The coordination polymers 1 and 2 were prepared by reactions of cobalt(II) nitrate hexahydrate or nickel(II) nitrate hexahydrate, respectively, 6-hydroxynicotinic acid and 4,4'bipyridine in the mixture of ethanol and water under hydrothermal conditions (Scheme 1). The said compounds can be prepared exclusively under hydrothermal conditions, as the 
syntheses attempts at normal pressure and room temperature lead to the crystallization of the ligands from the reaction mixtures.

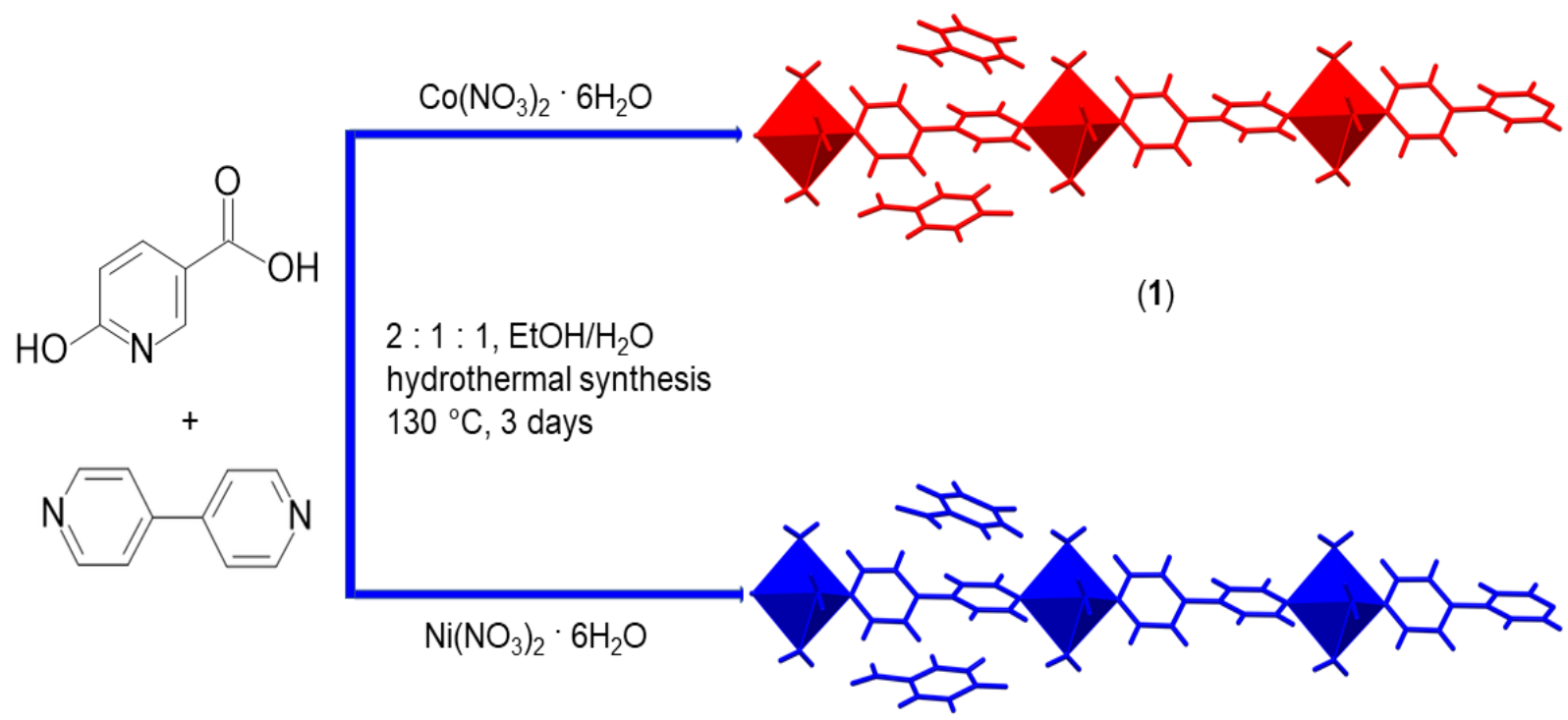

(2)

Scheme 1. Preparation of $\left\{\left[\mathrm{Co}\left(4,4^{\prime} \text {-bpy }\right)\left(\mathrm{H}_{2} \mathrm{O}\right)_{4}\right](6-\mathrm{Onic})_{2} \cdot 2 \mathrm{H}_{2} \mathrm{O}\right\}_{n}$ (1) and $\left\{\left[\mathrm{Ni}\left(4,4^{\prime} \text {-bpy) }\left(\mathrm{H}_{2} \mathrm{O}\right)_{4}\right](6-\text {-Onic })_{2} \cdot 2 \mathrm{H}_{2} \mathrm{O}\right\}_{n}\right.$ (2) under hydrothermal conditions.

\subsection{Crystal Structures}

The metal ions (cobalt(II) in $\mathbf{1}$ and nickel(II) in 2), nitrogen (N1 and N2) and carbon (C3 and (6) atoms are situated on a two-fold axis. Consequently, the asymmetric units of both $\mathbf{1}$ and $\mathbf{2}$ contain a half of a metal ion, two coordinated water molecules, a 6-oxonicotinate anion, a half of a 4,4'-bipyridine ligand and a lattice water molecule. The molecular structures of $\mathbf{1}$ and 2 contain a one-dimensional polymeric $\left\{\left[\mathrm{Co}\left(4,4^{\prime}-\text { bpy }\right)\left(\mathrm{H}_{2} \mathrm{O}\right)_{4}\right]^{2+}\right\}_{n}$ cation in $\mathbf{1}$ and a $\left\{\left[\mathrm{Ni}\left(4,4^{\prime} \text {-bpy) }\left(\mathrm{H}_{2} \mathrm{O}\right)_{4}\right]^{2+}\right\}_{n}\right.$ cation in 2 , respectively. Per repeating polymeric unit of $\mathbf{1}$ and 2, there are also two lattice water molecules and two 6-oxonicotinate anions in their keto tautomeric form (with the protonated pyridine nitrogen atoms) (Figure 1a,b).

Compounds 1 and $\mathbf{2}$ are isostructural, as can be seen from the overlay of the respective molecules of $\mathbf{1}$ and $\mathbf{2}$ (Figure 1c). Moreover, both compounds $\mathbf{1}$ and $\mathbf{2}$ crystallize in the same space group $(C 2 / c)$ and with the similar unit cell parameters (Table 1$)$. The metal(II) ions in the respective polymeric $\left\{\left[\mathrm{M}\left(4,4^{\prime}-\text { bpy }\right)\left(\mathrm{H}_{2} \mathrm{O}\right)_{4}\right]^{2+}\right\}_{n}$ cations $(\mathrm{M}=\mathrm{Co}, \mathrm{Ni})$ in $\mathbf{1}$ and 2 are octahedrally coordinated by four water molecule $\mathrm{O}$ atoms $\left(\mathrm{O} 1, \mathrm{O} 2, \mathrm{O}^{1}{ }^{\mathrm{i}}\right.$, and $\mathrm{O}^{\mathrm{i}}$ ) (symmetry code (i): $-x+1, y,-z+3 / 2)$ and by two $4,4^{\prime}$-bipyridine $\mathrm{N}$ atoms (N1 and $\mathrm{N} 2$ ) in the trans position $\left(\mathrm{N} 1-\mathrm{M}-\mathrm{N} 2=180^{\circ}\right.$ ) (Figure 1a,b; Table S1 in the Supplementary Materials).

The infinite one-dimensional polymeric chains of $\left\{\left[\mathrm{M}\left(4,4^{\prime}-\mathrm{bpy}\right)\left(\mathrm{H}_{2} \mathrm{O}\right)_{4}\right]^{2+}\right\}_{n}$ extend

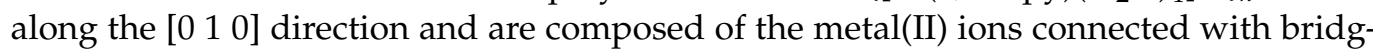
ing 4,4'-bipyridine ligands (Figure 2a). As can be seen from the angles for the trans $\left(175.8(2)^{\circ}\right.$ and $175.1(2)^{\circ}$ in $\mathbf{1}$ and $176.1(2)^{\circ}$ and $174.6(2)^{\circ}$ in 2$)$ and cis $\left(87.55(8)^{\circ}-92.45(8)^{\circ}\right.$ in 1 and $87.29(9)^{\circ}-92.71(9)^{\circ}$ in 2) pairs of the ligating atoms, the octahedral coordination environments around the metal(II) ions in $\mathbf{1}$ and $\mathbf{2}$ are only slightly distorted (Table S1 in the Supplementary Materials). The $\mathrm{M}-\mathrm{O}$ and $\mathrm{M}-\mathrm{N}$ bond lengths in $\mathbf{1}$ and $\mathbf{2}$ can be compared to the analogous bond lengths in the already known structures containing $\left\{\left[\mathrm{Co}\left(4,4^{\prime} \text {-bpy }\right)\left(\mathrm{H}_{2} \mathrm{O}\right)_{4}\right]^{2+}\right\}_{n}[32]$ or $\left\{\left[\mathrm{Ni}\left(4,4^{\prime}-\text { bpy }\right)\left(\mathrm{H}_{2} \mathrm{O}\right)_{4}\right]^{2+}\right\}_{n}$ cations [32-40]. 


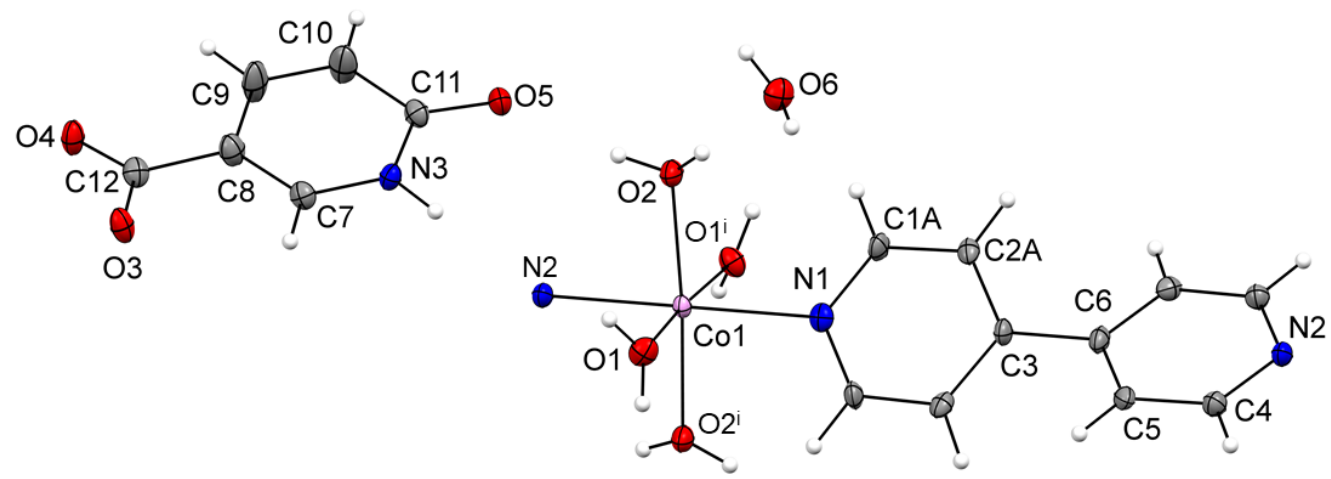

(a)
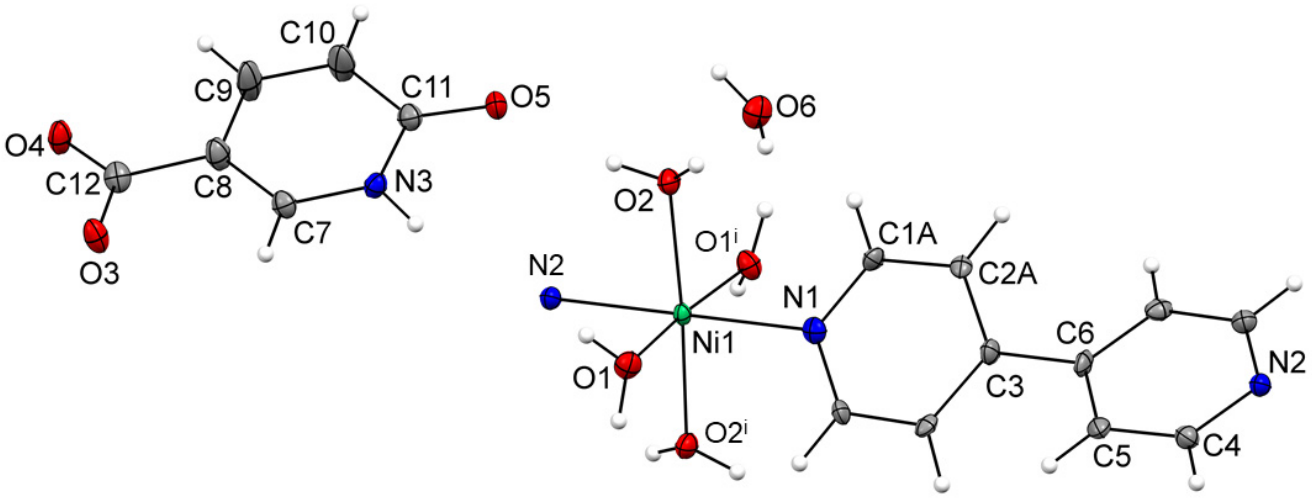

(b)
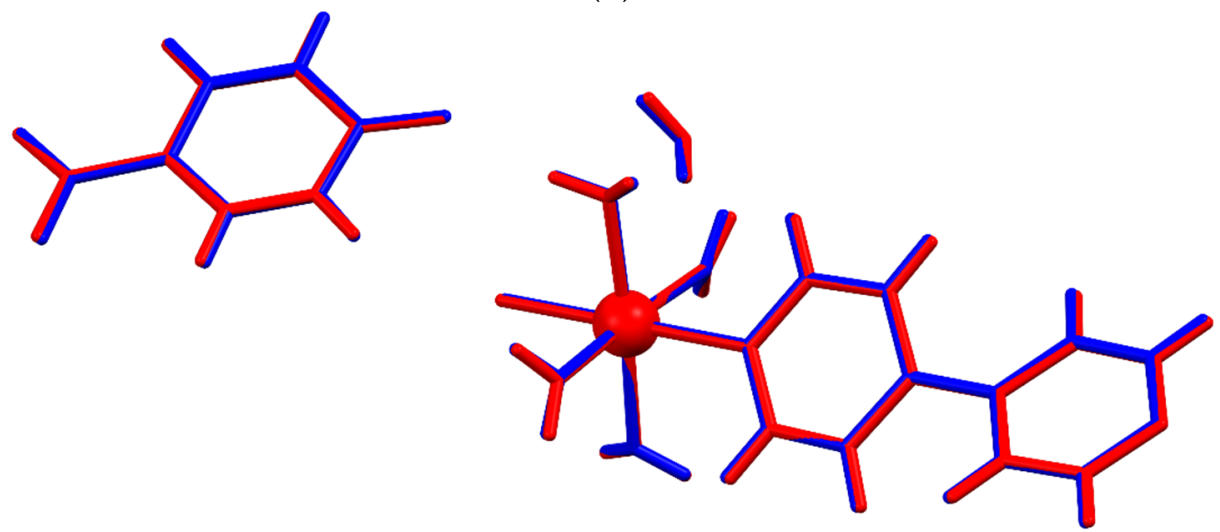

(c)

Figure 1. ORTEP-style plots of $\left\{\left[\mathrm{Co}\left(4,4^{\prime}-\text { bpy }\right)\left(\mathrm{H}_{2} \mathrm{O}\right)_{4}\right](6-\mathrm{Onic})_{2} \cdot 2 \mathrm{H}_{2} \mathrm{O}\right\}_{n}$ (1) (a) and $\left\{\left[\mathrm{Ni}\left(4,4^{\prime}\right.\right.\right.$ bpy) $\left.\left.\left(\mathrm{H}_{2} \mathrm{O}\right)_{4}\right](6-\text {-Onic })_{2} \cdot 2 \mathrm{H}_{2} \mathrm{O}\right\}_{n}$ (2) (b), with the atomic numbering schemes (symmetry code (i): $-x+1, y,-z+3 / 2)$. The thermal ellipsoids are drawn at the $50 \%$ probability level at $100(2) \mathrm{K}$ and hydrogen atoms are shown as spheres of arbitrary radii; the components of the disordered $\mathrm{C} 1$ and $\mathrm{C} 2$ atoms in 1 and 2 (C1B and C2B) are not shown. The overlay (RMS value of $0.0447 \AA$ ) (c) of $\left\{\left[\mathrm{Co}\left(4,4^{\prime}\right.\right.\right.$ bpy) $\left.\left.\left(\mathrm{H}_{2} \mathrm{O}\right)_{4}\right](6-\text { Onic })_{2} \cdot 2 \mathrm{H}_{2} \mathrm{O}\right\}_{n}(\mathbf{1})$ (red) and $\left\{\left[\mathrm{Ni}\left(4,4^{\prime} \text {-bpy) }\left(\mathrm{H}_{2} \mathrm{O}\right)_{4}\right](6-\mathrm{Onic})_{2} \cdot 2 \mathrm{H}_{2} \mathrm{O}\right\}_{n}\right.$ (2) (blue). The $\mathrm{Co}, \mathrm{Ni}, \mathrm{N}$, and $\mathrm{O}$ atoms were chosen for the overlay.

There are strong intermolecular $\mathrm{O}-\mathrm{H} \cdots \mathrm{O}$ and $\mathrm{N}-\mathrm{H} \cdots \mathrm{O}$ hydrogen bonds and weak $\mathrm{C}-\mathrm{H}$... O hydrogen bonds, observed in the structures of $\mathbf{1}$ and $\mathbf{2}$ (Table 2). The polymeric chains of $\left\{\left[\mathrm{M}\left(4,4^{\prime} \text {-bpy }\right)\left(\mathrm{H}_{2} \mathrm{O}\right)_{4}\right]^{2+}\right\}_{n}$, the 6-oxonicotinate anions and the lattice water molecules are connected by strong hydrogen bonds into hydrogen-bonded frameworks (Figure $2 b$ ). There are two types of $\pi-\pi$ interactions in the respective structures: 


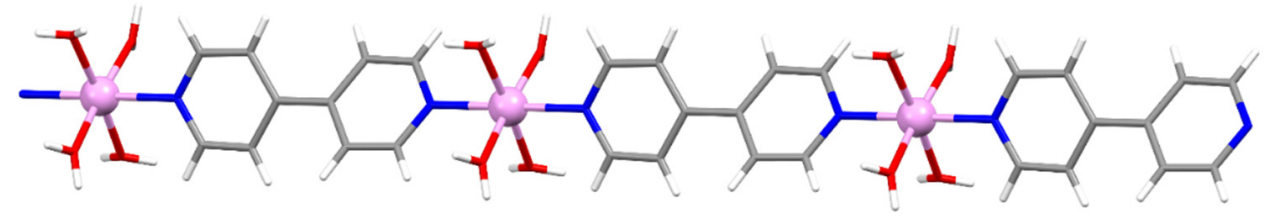

(a)

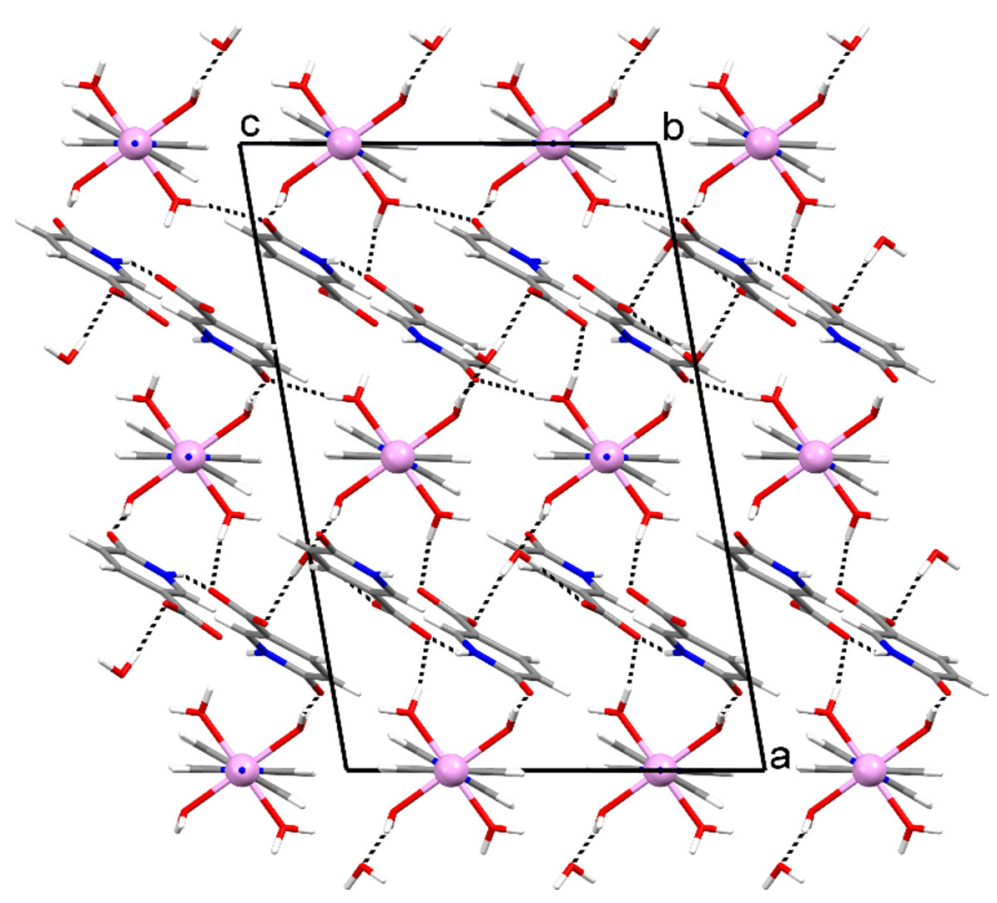

(b)

Figure 2. The infinite one-dimensional polymeric chain of $\left\{\left[\mathrm{Co}\left(4,4^{\prime}-\mathrm{bpy}\right)\left(\mathrm{H}_{2} \mathrm{O}\right)_{4}\right]^{2+}\right\}_{n}$ cation in $\mathbf{1}$, extending along the [0 10 l 0 d direction (a). A fragment of the infinite hydrogen-bonded framework of $\left\{\left[\mathrm{Co}\left(4,4^{\prime} \text {-bpy) }\left(\mathrm{H}_{2} \mathrm{O}\right)_{4}\right](6-\text { Onic })_{2} \cdot 2 \mathrm{H}_{2} \mathrm{O}\right\}_{n}(\mathbf{1})\right.$, viewed down the $\left[\begin{array}{ll}0 & 1\end{array}\right]$ direction $(\mathbf{b})$, with the $\left\{\left[\mathrm{Co}\left(4,4^{\prime}-\right.\right.\right.$ bpy) $\left.\left.\left(\mathrm{H}_{2} \mathrm{O}\right)_{4}\right]^{2+}\right\}_{n}$ cations (represented as monomeric molecules in this projection), 6-oxonicotinate anions and lattice water molecules being connected via strong intermolecular $\mathrm{O}-\mathrm{H} \cdots \mathrm{O}$ and $\mathrm{N}-\mathrm{H} \cdots \mathrm{O}$ hydrogen bonds (represented by the dotted lines).

$\pi-\pi$ interactions between $4,4^{\prime}$-bipyridine and 6-oxonicotinate pyridine rings [a $\mathrm{Cg} 1 \cdots$ Cg2 $(-x,-y, 1-z)$ distance $=3.871(2) \AA$ (in 1) and 3.874(2) $\AA$ (in 2); dihedral angle between the planes $=11.9(2)^{\circ}$ (in 1) and $12.2(2)^{\circ}$ (in 2); slippage $=1.368 \AA$ (in 1) and $1.355 \AA$ (in 2); $\mathrm{Cg} 1$ is the centroid of the $4,4^{\prime}$-bipyridine ring $\mathrm{N} 2 / \mathrm{C} 4 / \mathrm{C} 5 / \mathrm{C} 6 / \mathrm{C} 5^{\mathrm{i}} / \mathrm{C} 4^{\mathrm{i}}$ and $\mathrm{Cg} 2$ is the centroid of the 6-oxonicotinate pyridine ring N3/C7-C11], and $\pi-\pi$ interactions between symmetry-related 6-oxonicotinate pyridine rings N3/C7-C11 [a Cg2 ‥ Cg2 $(1 / 2-x, 1 / 2-y$, $1-z$ ) distance $=3.613(3) \AA$ (in 1) and 3.573(3) $\AA$ (in 2); dihedral angle between the planes = $0.0(2)^{\circ}$ in $\mathbf{1}$ and $\mathbf{2}$ and a slippage $=1.206 \AA$ (in $\mathbf{1}$ ) and $1.098 \AA$ (in 2)].

The polymeric chains of $\left\{\left[\mathrm{M}\left(4,4^{\prime} \text {-bpy }\right)\left(\mathrm{H}_{2} \mathrm{O}\right)_{4}\right]^{2+}\right\}_{n}$ are hydrogen-bonded solely to 6-oxonicotinate anions and lattice water molecules. However, besides being hydrogenbonded to other 6-oxonicotinate anions, lattice water molecules and polymeric $\left\{\left[\mathrm{M}\left(4,4^{\prime}-\right.\right.\right.$ bpy) $\left.\left.\left(\mathrm{H}_{2} \mathrm{O}\right)_{4}\right]^{2+}\right\}_{n}$ cations, the 6-oxonicotinate anions are additionally assembled together by $\pi-\pi$ interactions between symmetry-related 6-oxonicotinate pyridine rings $(\mathrm{Cg} 2 \cdots \mathrm{Cg} 2)$ within the hydrogen-bonded framework of $\mathbf{1}$ and $\mathbf{2}$.

The most distinguished hydrogen-bonded ring motifs within the frameworks of 1 and 2 are the trimeric $R_{3}^{2}(10)$ motif, the centrosymmetric tetrameric $R^{2}{ }_{4}(8)$ and $R^{2}{ }_{4}(12)$ motifs and the pentameric $R^{4}{ }_{5}(12)$ motif (Figure 3). 
Table 2. The hydrogen bond geometry for $\left\{\left[\mathrm{Co}\left(4,4^{\prime}-\mathrm{bpy}\right)\left(\mathrm{H}_{2} \mathrm{O}\right)_{4}\right](6-\mathrm{Onic})_{2} \cdot 2 \mathrm{H}_{2} \mathrm{O}\right\}_{n}(\mathbf{1})$ and $\left\{\left[\mathrm{Ni}\left(4,4^{\prime}-\mathrm{bpy}\right)\left(\mathrm{H}_{2} \mathrm{O}\right)_{4}\right](6-\right.$ Onic) $\left.)_{2} \cdot 2 \mathrm{H}_{2} \mathrm{O}\right\}_{n}(2)$.

\begin{tabular}{|c|c|c|c|c|c|}
\hline $\mathbf{D}-\mathbf{H} \cdots \mathbf{A}$ & $d(\mathrm{D}-\mathrm{H}) / \AA$ & $d(\mathbf{H} \cdots \mathbf{A}) / \AA$ & $d(\mathrm{D} \cdots \mathrm{A}) / \AA$ & $\angle(\mathbf{D}-\mathbf{H} \cdots \mathbf{A}) /^{\circ}$ & Symmetry Code on A \\
\hline \multicolumn{6}{|c|}{1} \\
\hline N3-H31‥O3 & $0.88(1)$ & $1.88(2)$ & $2.732(4)$ & $163(4)$ & $-x+1 / 2, y+1 / 2,-z+3 / 2$ \\
\hline $\mathrm{O} 1-\mathrm{H} 11 \cdots \mathrm{O} 5$ & $0.84(1)$ & $1.85(1)$ & $2.680(4)$ & $172(4)$ & $x,-y+1, z+1 / 2$ \\
\hline $\mathrm{O} 1-\mathrm{H} 12 \cdots \mathrm{O} 3$ & $0.84(1)$ & $1.87(1)$ & $2.699(4)$ & $169(4)$ & $-x+1 / 2, y+1 / 2,-z+3 / 2$ \\
\hline $\mathrm{O} 2-\mathrm{H} 21 \cdots \mathrm{O} 6$ & $0.84(1)$ & $1.87(1)$ & $2.704(4)$ & $170(5)$ & $x, y, z$ \\
\hline $\mathrm{O} 2-\mathrm{H} 22 \cdots \mathrm{O} 5$ & $0.84(1)$ & $1.90(2)$ & $2.729(4)$ & $167(5)$ & $x, y, z$ \\
\hline $\mathrm{O} 6-\mathrm{H} 61 \cdots \mathrm{O} 4$ & $0.84(1)$ & $1.99(1)$ & $2.823(4)$ & $175(5)$ & $-x+1 / 2,-y+1 / 2,-z+1$ \\
\hline $\mathrm{O} 6-\mathrm{H} 62 \cdots \mathrm{O} 4$ & $0.84(1)$ & 1.92(1) & $2.755(4)$ & $175(4)$ & $x, y+1, z$ \\
\hline C1B-H1B $\cdots$ O1 & 0.95 & 2.45 & $2.989(9)$ & 116 & $-x+1, y,-z+3 / 2$ \\
\hline 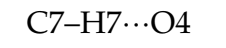 & 0.95 & 2.60 & $3.287(5)$ & 130 & $-x+1 / 2, y+1 / 2,-z+3 / 2$ \\
\hline \multicolumn{6}{|r|}{ 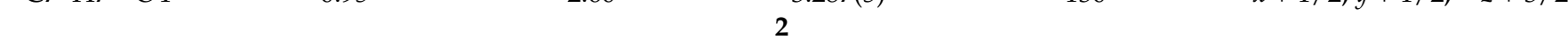 } \\
\hline N3-H31‥O3 & $0.88(1)$ & $1.88(2)$ & $2.721(4)$ & $161(4)$ & $-x+1 / 2, y+1 / 2,-z+3 / 2$ \\
\hline 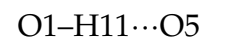 & $0.84(1)$ & $1.86(2)$ & $2.687(4)$ & $166(5)$ & $x,-y+1, z+1 / 2$ \\
\hline $\mathrm{O} 1-\mathrm{H} 12 \cdots \mathrm{O} 3$ & $0.84(1)$ & $1.86(1)$ & $2.696(4)$ & $171(4)$ & $-x+1 / 2, y+1 / 2,-z+3 / 2$ \\
\hline $\mathrm{O} 2-\mathrm{H} 21 \cdots \mathrm{O} 6$ & $0.84(1)$ & $1.87(1)$ & $2.702(4)$ & $172(5)$ & $x, y, z$ \\
\hline $\mathrm{O} 2-\mathrm{H} 22 \cdots \mathrm{O} 5$ & $0.84(1)$ & $1.90(2)$ & $2.724(4)$ & $165(5)$ & $x, y, z$ \\
\hline $\mathrm{O} 6-\mathrm{H} 61 \cdots \mathrm{O} 4$ & $0.84(1)$ & $1.99(1)$ & $2.823(4)$ & $175(4)$ & $-x+1 / 2,-y+1 / 2,-z+1$ \\
\hline $\mathrm{O} 6-\mathrm{H} 62 \cdots \mathrm{O} 4$ & $0.84(1)$ & $1.91(1)$ & $2.748(4)$ & $174(5)$ & $x, y+1, z$ \\
\hline C1B-H1B $\cdots \mathrm{O} 1$ & 0.95 & 2.40 & 2.923(9) & 115 & $-x+1, y,-z+3 / 2$ \\
\hline $\mathrm{C} 7-\mathrm{H} 7 \cdots \mathrm{O} 4$ & 0.95 & 2.57 & $3.270(5)$ & 131 & $-x+1 / 2, y+1 / 2,-z+3 / 2$ \\
\hline
\end{tabular}

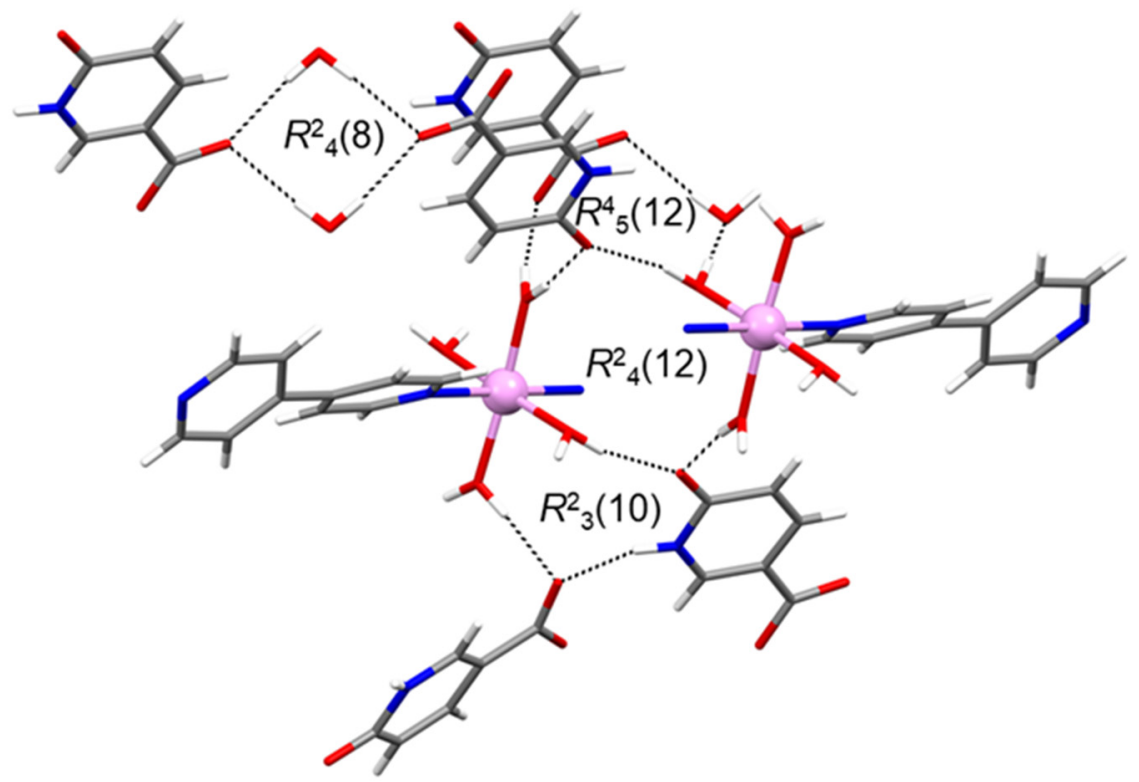

Figure 3. The most distinguished hydrogen-bonded ring motifs (shown by dotted lines) found within the hydrogen-bonded framework of $\left\{\left[\mathrm{Co}\left(4,4^{\prime}-\mathrm{bpy}\right)\left(\mathrm{H}_{2} \mathrm{O}\right)_{4}\right](6-\mathrm{Onic})_{2} \cdot 2 \mathrm{H}_{2} \mathrm{O}\right\}_{n}$ (1), e.g., the trimeric $R_{3}^{2}(10)$ motif, the centrosymmetric tetrameric $R^{2}{ }_{4}(8)$ and $R^{2}{ }_{4}(12)$ motifs and the pentameric $R^{4}{ }_{5}(12)$ motif.

The trimeric $R^{2}{ }_{3}(10)$ motif is formed between two 6-oxonicotinate anions (one of them linked via an oxo atom and a pyridinium $\mathrm{N}$ atom, the other via carboxylate $\mathrm{O}$ atom) and a polymeric cation (linked via two coordinated water molecules). The tetrameric $R^{2}{ }_{4}(8)$ motif is formed between two lattice water molecules and two 6-oxonicotinate ions (both linked via a single carboxylate $\mathrm{O}$ atom). In addition, a tetrameric $R^{2}{ }_{4}(12)$ motif is formed between two polymeric cations (both linked via two coordinated water molecules) and two 6-oxonicotinate anions (both linked via a single oxo atom). The pentameric $R^{4}{ }_{5}(12)$ motif is formed between two polymeric cations (both linked via a single coordinated water 
molecule), two 6-oxonicotinate anions (one of them linked via two carboxylate $\mathrm{O}$ atoms and the other via oxo atom) and a single lattice water molecule.

\subsection{Thermal Analysis}

The TGA/DTA curves of compounds $\mathbf{1}$ and $\mathbf{2}$ are almost identical, as it would be expected for isostructural compounds (Figures S5 and S6 in the Supplementary Materials). Both compounds are thermally stable up to $100{ }^{\circ} \mathrm{C}$, followed by a release of four coordinated and two lattice water molecules in a single step with an endothermic peak at $137.2{ }^{\circ} \mathrm{C}$ in $\mathbf{1}$ and $143.3{ }^{\circ} \mathrm{C}$ in $\mathbf{2}$ (observed mass losses $18.4 \%$ in $\mathbf{1}$ and $18.6 \%$ in $\mathbf{2}$, calculated $18.0 \%$ in $\mathbf{1}$ and 2). Both coordinated and lattice water molecules are released at the same temperature most probably due to the existence of thermally stable hydrogenbonded frameworks of $\mathbf{1}$ and $\mathbf{2}$ (as revealed by their crystal structures), in which these water molecules participate extensively. Therefore, their simultaneous release upon the collapse of hydrogen-bonded frameworks of $\mathbf{1}$ and $\mathbf{2}$ is expected. The thermal decomposition of $\mathbf{1}$ and $\mathbf{2}$ continues through two consecutive, not well-resolved steps; first one representing an endothermic process (peaks at $342.7^{\circ} \mathrm{C}$ in 1 and $350.2^{\circ} \mathrm{C}$ in 2) and the second representing an exothermic process (peaks at $403.5^{\circ} \mathrm{C}$ in 1 and $394.9^{\circ} \mathrm{C}$ in 2). These endothermic (observed mass losses $41.9 \%$ in 1 and $34.7 \%$ in 2) and exothermic (observed mass losses $27.5 \%$ in $\mathbf{1}$ and $36.0 \%$ in 2 ) steps correspond to the complete decomposition of 6-oxonicotinate and 4, $4^{\prime}$-bipyridine ligands. The observed residues $(12.2 \%$ in $\mathbf{1}$ and $10.7 \%$ in 2) at $800{ }^{\circ} \mathrm{C}$ correspond to $\mathrm{CoO}$ in the case of $\mathbf{1}$ and to $\mathrm{NiO}$ in the case of 2 . The last decomposition steps in $\mathbf{1}$ and $\mathbf{2}$ are exothermic, which is in accordance with the formation of thermodynamically stable metal oxides $(\mathrm{CoO}$ and $\mathrm{NiO})$ upon total decomposition of $\mathbf{1}$ and $\mathbf{2}$, respectively.

\subsection{Electrochemical Characterization}

The electrochemical properties of the modified glassy carbon (GC) electrodes were investigated by cyclic voltammetry $(\mathrm{CV})$ and electrochemical impedance spectroscopy (EIS) using a solution of $1 \mathrm{mmol} \mathrm{L}^{-1}\left[\mathrm{Fe}(\mathrm{CN})_{6}\right]^{3-/ 4-}$ in $0.1 \mathrm{~mol} \mathrm{~L}^{-1} \mathrm{KNO}_{3}$. Figure 4 shows $\mathrm{CVs}$ of $1 \mathrm{mmol} \mathrm{L}^{-1}\left[\mathrm{Fe}(\mathrm{CN})_{6}\right]^{3-/ 4-}$ and $0.1 \mathrm{~mol} \mathrm{~L}^{-1} \mathrm{KNO}_{3}$ at multi-walled carbon nanotubes (MWCNT) electrode, MWCNT | 1 electrode and MWCNT $\mid 2$ electrode, recorded in a potential range from -0.2 to $0.6 \mathrm{~V}$ (vs. $\mathrm{Ag} / \mathrm{AgCl}$ ) with a scan rate of $50 \mathrm{mV} \mathrm{s}^{-1}$. Potential ranges depend on the nature of electrode material and is established after recording in a wider potential range. Those limits agreed roughly with the potential range characteristic for $\mathrm{Fe}(\mathrm{III}) / \mathrm{Fe}(\mathrm{II})$ redox couple.

As observed in Figure 4, the MWCNT 2 electrode exhibits two redox waves, one quasireversible $\left(\Delta E_{\mathrm{p}}\right.$ is much larger than theoretical value [41]) and one reversible. The quasireversible peak corresponds to the $\mathrm{Fe}(\mathrm{III}) / \mathrm{Fe}(\mathrm{II})$ couple, $E_{\mathrm{pa} 1}=0.462 \mathrm{~V}, E_{\mathrm{pc} 1}=-0.086 \mathrm{~V}$, and the average formal potential $E_{1 / 2}$ is $0.188 \mathrm{~V}$. The peak-to-peak separation between the anodic and cathodic peaks $\left(\Delta E_{\mathrm{p}}\right)$ is $0.548 \mathrm{~V}$. The ratio of cathodic peak current to anodic peak current $\left(i_{\mathrm{pc} 1} / i_{\mathrm{pa} 1}\right)$ is $-20.826\left(i_{\mathrm{pc} 1}=-45.40 \mu \mathrm{A}, i_{\mathrm{pa} 1}=2.18 \mu \mathrm{A}\right)$, and the ratio of anodic peak current to cathodic peak current $\left(i_{\mathrm{pa} 1} / i_{\mathrm{pc} 1}\right)$ is -0.048 . The second reduction peak at ca. $0.406 \mathrm{~V}$ vs. $\mathrm{Ag} / \mathrm{AgCl}$ corresponds to the reduction of 2 . The anodic peak corresponds to $\mathrm{Fe}(\mathrm{III}) / \mathrm{Fe}$ (II) couple obtained at MWCNT $\mid \mathbf{1}$ and is significantly lower than those obtained at MWCNT. In all cases, the broadened and little defined peaks are obtained with the higher oxidation potential (compound 1, $E_{\mathrm{p}, \mathrm{a}}=467 \mathrm{mV}$, and compound 2, $\left.E_{\mathrm{p}, \mathrm{a}}=462 \mathrm{mV}\right)$ with respect to the MWCNT $\left(E_{\mathrm{p}, \mathrm{a}}=0.269 \mathrm{mV}\right)$, revealing an electroinhibitory effect of the $\mathbf{1}$ and $\mathbf{2}$ on the $\mathrm{Fe}(\mathrm{III}) / \mathrm{Fe}(\mathrm{II})$ redox reaction. The large peak-topeak separation in the corresponding cyclic voltammograms $(\Delta E 548 \mathrm{mV}$ vs. $\Delta E 146 \mathrm{mV}$ of the MWCNT) in comparison with the MWCNT electrode can also be attributed to the significant electroinhibitory effect of the $\mathbf{1}$ and $\mathbf{2}$ on the $\mathrm{Fe}(\mathrm{III}) / \mathrm{Fe}(\mathrm{II})$ redox reaction.

Cyclic voltammograms suggest very similar behavior of both 1 and 2 vs. $\mathrm{Fe}(\mathrm{III}) / \mathrm{Fe}(\mathrm{II})$ redox reaction, while in the case of polymer 2 there is an additional redox pair corresponding to a redox reaction of polymer 2 . The observed differences can be related to 
the reaction between 2 and the $\mathrm{Fe}(\mathrm{III}) / \mathrm{Fe}(\mathrm{II})$ system and can be attributed to the different electronic configurations of cobalt(II) and nickel(II) ions, leading to a different reactivity of $\mathbf{1}$ and $\mathbf{2}$ towards the $\mathrm{Fe}(\mathrm{III}) / \mathrm{Fe}(\mathrm{II})$ system.

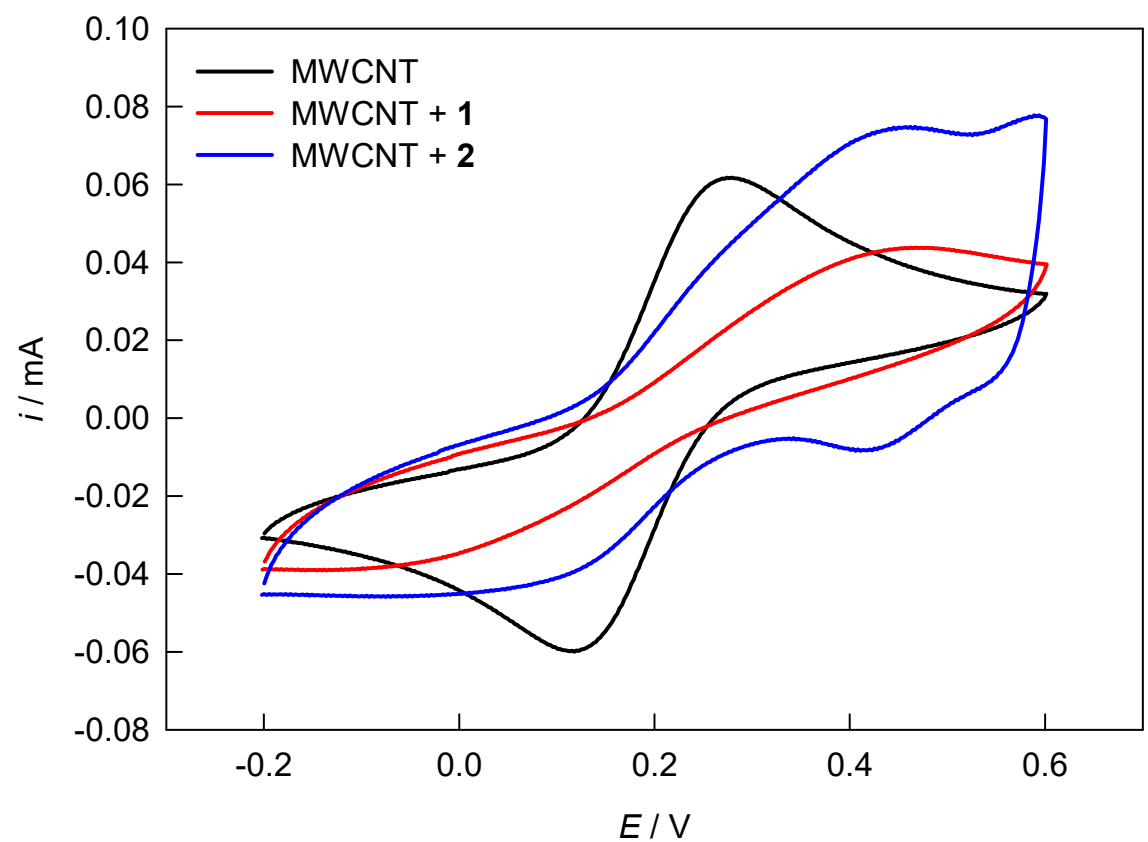

Figure 4. Cyclic voltammograms of the $1 \mathrm{mmol} \mathrm{L}^{-1}\left[\mathrm{Fe}(\mathrm{CN})_{6}\right]^{3-/ 4-}$ redox probe in $0.1 \mathrm{~mol} \mathrm{~L}^{-1}$ $\mathrm{KNO}_{3}$ (pH 7.0) at MWCNT electrode, MWCNT $\mid 1$ electrode and MWCNT $\mid 2$ electrode recorded with a scan rate of $50 \mathrm{mV} \mathrm{s}^{-1}$.

\section{Conclusions}

The introduction of a hydroxyl substituent (instead of a chlorine atom) at position -6 in the pyridine ring of nicotinate ligands did not affect either coordination environments of the metal ions (cobalt(II), nickel(II)) or structural type of the obtained 1D coordination polymers $\mathbf{1}$ and 2, if compared to the structurally analogous nickel(II) coordination polymer with 6-chloronicotinate and 4,4'-bipyridine ligands, $\left\{\left[\mathrm{Ni}\left(4,4^{\prime}-\text { bpy }\right)\left(\mathrm{H}_{2} \mathrm{O}\right)_{4}\right](6-\mathrm{Clnic})_{2} \cdot 4 \mathrm{H}_{2} \mathrm{O}\right\}_{n}$. The only difference is in the number of lattice water molecules [26]. Indeed, the hydroxyl substituent participates more extensively in the hydrogen bonding than it was the case with chlorine substituent, leading to the different hydrogen-bond motifs in the hydrogenbonded frameworks of $\mathbf{1}$ and 2, as compared to $\left\{\left[\mathrm{Ni}\left(4,4^{\prime}-\text { bpy }\right)\left(\mathrm{H}_{2} \mathrm{O}\right)_{4}\right](6-\mathrm{Clnic})_{2} \cdot 4 \mathrm{H}_{2} \mathrm{O}\right\}_{n}$ (only $R^{2}{ }_{4}(8)$ motif is the same). However, other motifs are related, differing only in the ring size (e.g., $R^{4}{ }_{5}(12)$ and $R^{2}{ }_{4}(12)$ in 1 and 2 comparing to $R^{4}{ }_{5}(16)$ and $R^{2}{ }_{4}(8)$ in $\left\{\left[\mathrm{Ni}\left(4,4^{\prime}\right.\right.\right.$ bpy) $\left.\left.\left(\mathrm{H}_{2} \mathrm{O}\right)_{4}\right](6-\mathrm{Clnic})_{2} \cdot 4 \mathrm{H}_{2} \mathrm{O}\right\}_{n}$, respectively) [26].

The electrochemical studies of coordination polymers $\mathbf{1}$ and $\mathbf{2}$ showed that the reduction is metal-centered, and only polymer 2 underwent a reduction in the region of potentials from -0.2 to $0.6 \mathrm{~V}$ vs. $\mathrm{Ag} \mid \mathrm{AgCl}$, while polymer 1 did not exhibit any redox activity. This different electrochemical behavior of the isostructural 1 and 2 can be attributed to the nature of metal ions (cobalt(II) vs. nickel(II)). Both metal ions have different electronic configurations, leading to a different reactivity of $\mathbf{1}$ and $\mathbf{2}$ towards the Fe(III)/Fe(II) system.

Supplementary Materials: The following are available online at https: / www.mdpi.com/article / 10.3390 / chemosensors $9120352 /$ s1, Table S1. Selected bond lengths $(\AA)$ and angles $\left({ }^{\circ}\right)$ for $\left\{\left[\operatorname{Co}\left(4,4^{\prime}-\right.\right.\right.$ bpy) $\left.\left.\left(\mathrm{H}_{2} \mathrm{O}\right)_{4}\right](6-\mathrm{Onic})_{2} \cdot 2 \mathrm{H}_{2} \mathrm{O}\right\}_{n}(\mathbf{1})$ and $\left\{\left[\mathrm{Ni}\left(4,4^{\prime}-\text {-bpy }\right)\left(\mathrm{H}_{2} \mathrm{O}\right)_{4}\right](6-\mathrm{Onic})_{2} \cdot 2 \mathrm{H}_{2} \mathrm{O}\right\}_{n}(2)$, Figure S1. IR spectrum of $\left\{\left[\mathrm{Co}\left(4,4^{\prime}-\mathrm{bpy}\right)\left(\mathrm{H}_{2} \mathrm{O}\right)_{4}\right](6-\mathrm{Onic})_{2} \cdot 2 \mathrm{H}_{2} \mathrm{O}\right\}_{n}(\mathbf{1})$, Figure S2. IR spectrum of $\left\{\left[\mathrm{Ni}\left(4,4^{\prime}-\mathrm{bpy}\right)\left(\mathrm{H}_{2} \mathrm{O}\right)_{4}\right](6-\right.$ Onic) $\left.)_{2} \cdot 2 \mathrm{H}_{2} \mathrm{O}\right\}_{n}(2)$, Figure S3. Cyclic voltammograms recorded in a broader range at MWCNT electrode, MWCNT I 1 electrode and MWCNT I 2 electrode in $0.1 \mathrm{~mol} \mathrm{~L}^{-1} \mathrm{KNO}_{3}$ solution ( $\mathrm{pH}$ 7.0), Figure S4. Electrochemical impedance spectra of the $1 \mathrm{mmol} \mathrm{L}^{-1}\left[\mathrm{Fe}(\mathrm{CN})_{6}\right]^{3-/ 4-}$ redox probe in $0.1 \mathrm{~mol} \mathrm{~L}^{-1} \mathrm{KNO}_{3}\left(\mathrm{pH}\right.$ 7.0) recorded at $E_{\mathrm{ocp}}$ for MWCNT electrode, MWCNT I 1 electrode and 
MWCNT I 2 electrode, Figure S5. TGA/DTA curve of $\left\{\left[\mathrm{Co}\left(4,4^{\prime}-\mathrm{bpy}\right)\left(\mathrm{H}_{2} \mathrm{O}\right)_{4}\right](6-\mathrm{Onic})_{2} \cdot 2 \mathrm{H}_{2} \mathrm{O}\right\}_{n}$ (1), Figure S6. TGA/DTA curve of $\left\{\left[\mathrm{Ni}\left(4,4^{\prime}-\mathrm{bpy}\right)\left(\mathrm{H}_{2} \mathrm{O}\right)_{4}\right](6-\mathrm{Onic})_{2} \cdot 2 \mathrm{H}_{2} \mathrm{O}\right\}_{n}$ (2). Deposition numbers 2122274 (for 1 ) and 2122275 (for 2) contain the supplementary crystallographic data for this paper.

Author Contributions: Conceptualization, C.L.O. and B.-M.K.; methodology, all authors; valida tion, all authors; formal analysis, I.Š.R., C.L.O. and B.-M.K.; investigation, all authors; resources, I.Š.R., N.V., V.S., C.L.O. and B.-M.K.; data curation C.L.O. and B.-M.K.; writing-original draft preparation, I.Š.R. and B.-M.K.; writing—review and editing, all authors; visualization, I.Š.R. and B.-M.K.; project administration, B.-M.K.; funding acquisition, I.Š.R., N.V., V.S., C.L.O. and B.-M.K. All authors have read and agreed to the published version of the manuscript.

Funding: This research and the APC were funded by the Faculty of Chemistry and Technology, University of Split institutional funding. C.L.O. also thanks the National Research Foundation of South Africa for funding (grant no: 120849).

Data Availability Statement: These data are provided free of charge by the joint Cambridge Crystallographic Data Centre and Fachinformationszentrum Karlsruhe Access Structures service at www.ccdc.cam.ac.uk/structures.

Conflicts of Interest: The authors declare no conflict of interest. The funders had no role in the design of the study; in the collection, analyses, or interpretation of data; in the writing of the manuscript, or in the decision to publish the results.

\section{References}

1. Li, J.-X.; Du, Z.-X.; Xiong, L.-Y.; Fu, L.-L.; Bo, W.-B. Supramolecular isomerism in two nickel(II) coordination polymers constructed with the flexible 2-carboxyphenoxyacetate linker: Syntheses, structure analyses and magnetic properties. J. Solid State Chem. 2021, 293, 121799. [CrossRef]

2. Bosch, M.; Yuan, S.; Rutledge, W.; Zhou, H.-C. Stepwise synthesis of metal-organic frameworks. Acc. Chem. Res. 2017, 50, 857-865. [CrossRef] [PubMed]

3. Zhang, W.-X.; Liao, P.-Q.; Lin, R.-B.; Wei, Y.-S.; Zeng, M.-H.; Chen, X.-M. Metal cluster-based functional porous coordination polymers. Coord. Chem. Rev. 2015, 293-294, 263-278. [CrossRef]

4. Zeng, M.-H.; Yin, Z.; Liu, Z.-H.; Xu, H.-B.; Feng, Y.-C.; Hu, Y.-Q.; Chang, L.-X.; Zhang, Y.-X.; Huang, J.; Kurmoo, M. Assembly of a highly stable luminescent $\mathrm{Zn}_{5}$ cluster and application to bio-imaging. Angew. Chem. Int. Ed. 2016, 55, 11407-11411. [CrossRef]

5. Zeng, M.-H.; Yin, Z.; Tan, Y.-X.; Zhang, W.-X.; He, Y.-P.; Kurmoo, M. Nanoporous cobalt(II) MOF exhibiting four magnetic ground states and changes in gas sorption upon post-synthetic modification. J. Am. Chem. Soc. 2014, 136, 4680-4688. [CrossRef]

6. Douvali, A.; Tsipis, A.C.; Eliseeva, S.V.; Petoud, S.; Papaefstathiou, G.S.; Malliakas, C.D.; Papadas, I.; Armatas, G.S.; Margiolaki, I.; Kanatzidis, M.G.; et al. Turn-on luminescence sensing and real-time detection of traces of water in organic solvents by a flexible metal-organic framework. Angew. Chem. Int. Ed. 2015, 54, 1651-1656. [CrossRef] [PubMed]

7. Xu, M.; Yuan, S.; Chen, X.-Y.; Chang, Y.-J.; Day, G.; Gu, Z.-Y.; Zhou, H.-C. Two-dimensional metal-organic framework nanosheets as an enzyme inhibitor: Modulation of the $\alpha$-chymotrypsin activity. J. Am. Chem. Soc. 2017, 139, 8312-8319. [CrossRef]

8. Zhou, Z.; He, C.; Yang, L.; Wang, Y.; Liu, T.; Duan, C. Alkyne activation by a porous silver coordination polymer for heterogeneous catalysis of carbon dioxide cycloaddition. ACS Catal. 2017, 7, 2248-2256. [CrossRef]

9. Suh, M.P.; Cheon, Y.E.; Lee, E.Y. Syntheses and functions of porous metallosupramolecular networks. Coord. Chem. Rev. 2008, 252, 1007-1026. [CrossRef]

10. Swiegers, G.F.; Malefetse, T.J. New self-assembled structural motifs in coordination chemistry. Chem. Rev. 2000, 100, 3483-3538. [CrossRef]

11. Wen, L.; Lu, Z.; Lin, L.G.; Tian, Z.; Zhu, H.; Meng, Q. Syntheses, structures, and physical properties of three novel metal-organic frameworks constructed from aromatic polycarboxylate acids and flexible imidazole-based synthons. Cryst. Growth Des. 2007, 7, 93-99. [CrossRef]

12. Wang, Y.; Englert, U. The first linear coordination oligomer linked by 4,4'-bipyridine. Eur. J. Inorg. Chem. 2007, 5623-5625. [CrossRef]

13. Schönfeld, S.; Dankhoff, K.; Baabe, D.; Zaretzke, M.-K.; Bröring, M.; Schötz, K.; Köhler, A.; Hörner, G.; Weber, B. Iron(II) spin crossover complexes based on a redox active equatorial Schiff-base-like ligand. Inorg. Chem. 2020, 59, 8320-8333. [CrossRef] [PubMed]

14. Karushev, M.A. Novel cobalt metallopolymer with redox-matched conjugated organic backbone via electropolymerization of a readily available $\mathrm{N}_{4}$ cobalt complex. Polymers 2021, 13, 1667. [CrossRef] [PubMed]

15. Wang, C.; Ding, D.; Jiang, X.; Zhou, B. Electrochemical sensors based on copper-cadmium bimetallic porphyrin coordination polymers with various $\mathrm{Cu} / \mathrm{Cd}$ ratios. J. Analyt. Chem. 2021, 76, 772-778. [CrossRef]

16. Wang, Y.; Ma, J.-X.; Zhang, Y.; Xu, N.; Wang, X.-L. A series of cobalt-based coordination polymer crystalline materials as highly sensitive electrochemical sensors for detecting trace $\mathrm{Cr}(\mathrm{VI})$, Fe(III) ions, and ascorbic acid. Cryst. Growth Des. 2021, 21, $4390-4397$. [CrossRef] 
17. Huang, Y.; Luo, M.; Li, S.; Xia, D.; Tang, Z.; Hu, S.; Ye, S.; Sun, M.; He, C.; Shu, D. Efficient catalytic activity and bromate minimization over lattice oxygen-rich $\mathrm{MnOOH}$ nanorods in catalytic ozonation of Bromide-containing organic pollutants: Lattice oxygen-directed redox cycle and bromate reduction. J. Hazard. Mater. 2021, 410, 124545. [CrossRef]

18. Yuan, B.; Zhang, J.; Zhang, R.; Shi, H.; Wang, N.; Li, J.; Ma, F.; Zhang, D. Cu-based metal-organic framework as a novel sensing platform for the enhanced electro-oxidation of nitrite. Sens. Actuators B 2016, 222, 632-637. [CrossRef]

19. Li, L.; Wang, X.; Xu, N.; Chang, Z.; Liu, G.; Lin, H.; Wang, X. Four octamolybdate complexes constructed from a quinoline-imidazole-monoamide ligand: Structures and electrochemical, photocatalytic and magnetic properties. CrystEngComm 2020, 22, 8322-8329. [CrossRef]

20. Cui, Z.-W.; Wang, X.-L.; Lin, H.-Y.; Xu, N.; Wang, X.; Liu, G.-C.; Chang, Z.-H. Two Anderson-type polyoxometalate-based metal-organic complexes with a flexible bis(pyrazine)-bis(amide) ligand for rapid adsorption and selective separation of cationic dyes. Inorg. Chim. Acta 2020, 513, 119937. [CrossRef]

21. Zhou, S.F.; Hao, B.B.; Lin, T.; Zhang, C.X. A dual-functional MOF for high proton conduction and sensitive detection of ascorbic acid. Dalton Trans. 2020, 49, 14490-14496. [CrossRef]

22. Li, Y.; Xie, M.; Zhang, X.; Liu, Q.; Lin, D.; Xu, C.; Xie, F.; Sun, X. Co-MOF nanosheet array: A high-performance electrochemical sensor for non-enzymatic glucose detection. Sens. Actuators B 2019, 278, 126-132. [CrossRef]

23. Pang, L.Y.; Wang, P.; Gao, J.J.; Wen, Y.; Liu, H. An active metal-organic anion framework with highly exposed $\mathrm{SO}_{4}{ }^{2-}$ on $\left.^{2} 001\right\}$ facets for the enhanced electrochemical detection of trace $\mathrm{Fe}^{3+}$. J. Electroanal. Chem. 2019, 836, 85-93. [CrossRef]

24. Hok, L.; Lluch Sanchez, E.; Vianello, R.; Kukovec, B.-M.; Popović, Z. Self-assembly of cobalt(II) coordination polymers with differently halosubstituted nicotinate ligands and 4,4'-bipyridine-The effect of the halosubstituent positions on polymer types. Eur. J. Inorg. Chem. 2021, 1470-1480. [CrossRef]

25. Politeo, N.; Pisačić, M.; Đaković, M.; Sokol, V.; Kukovec, B.-M. The first coordination compound of 6-fluoronicotinate: The crystal structure of a one-dimensional nickel(II) coordination polymer containing the mixed ligands 6-fluoronicotinate and 4,4'-bipyridine. Acta Crystallogr. 2020, E76, 500-505. [CrossRef]

26. Politeo, N.; Pisačić, M.; Đaković, M.; Sokol, V.; Kukovec, B.-M. Synthesis and crystal structure of a 6-chloronicotinate salt of a one-dimensional cationic nickel(II) coordination polymer with 4,4'-bipyridine. Acta Crystallogr. 2020, E76, 599-604. [CrossRef]

27. SAINT (including XPREP); Bruker AXS Inc.: Madison, WI, USA, 2012.

28. Sheldrick, G.M. SADABS: Area-Detector Absorption Correction; University of Göttingen: Göttingen, Germany, 1996.

29. Sheldrick, G.M. SHELXT_-Integrated space-group and crystal-structure determination. Acta Crystallogr. 2015, A71, 3-8. [CrossRef]

30. Sheldrick, G.M. Crystal structure refinement with SHELXL. Acta Crystallogr. 2015, C71, 3-8.

31. Macrae, C.F.; Sovago, I.; Cottrell, S.J.; Galek, P.T.A.; McCabe, P.; Pidcock, E.; Platings, M.; Shields, G.P.; Stevens, J.S.; Towler, M.; et al. Mercury 4.0: From visualization to analysis, design and prediction. J. Appl. Crystallogr. 2020, 53, 226-235. [CrossRef] [PubMed]

32. Groom, C.R.; Bruno, I.J.; Lightfoot, M.P.; Ward, S.C. The Cambridge Structural Database. Acta Crystallogr. 2016, B72, 171-179. [CrossRef] [PubMed]

33. Zheng, Y.-Q.; Kong, Z.-P.; Lin, J.-L. Crystal structure of tetraaqua(4,4'-bipyridine- $\left.N, N^{\prime}\right)$ nickel(II) fumarate tetrahydrate, $\mathrm{Ni}\left(\mathrm{H}_{2} \mathrm{O}\right)_{4}\left(\mathrm{C}_{10} \mathrm{H}_{8} \mathrm{~N}_{2}\right)\left(\mathrm{C}_{4} \mathrm{H}_{2} \mathrm{O}_{4}\right) \cdot 4 \mathrm{H}_{2} \mathrm{O}$. Z. Kristallogr. New Cryst. Struct. 2002, 217, 195-196. [CrossRef]

34. Gong, Y.-N.; Liu, C.-B.; Huang, D.-H.; Xiong, Z.-Q. Crystal structure of tetraaqua-(4,4'-bipyridyl)zinc(II) 3-(4-(carboxymethoxy) phenyl)propanoate, $\left[\mathrm{Ni}\left(\mathrm{H}_{2} \mathrm{O}\right)_{4}\left(\mathrm{C}_{10} \mathrm{H}_{8} \mathrm{~N}_{2}\right)\right]\left[\mathrm{C}_{11} \mathrm{H}_{10} \mathrm{O}_{5}\right]$. Z. Kristallogr. New Cryst. Struct. 2009, 224, 421-422. [CrossRef]

35. Li, N.-Y. catena-Poly[[[tetraaquanickel(II)]- $\mu-4,4^{\prime}$-bipyridyl- $\left.\kappa^{2} N: N^{\prime}\right]$ 3,3'-(p-phenylene)diacrylate]. Acta Crystallogr. 2011, E67, m1397. [CrossRef]

36. Gao, P.; Bai, H.; Bing, Y.-Y.; Hu, M. Syntheses, structures, and properties of transition metal coordination polymers based on a long semirigid tetracarboxylic acid and multidentate N-donor ligands. Solid State Sci. 2016, 52, 118-125. [CrossRef]

37. Sun, C.-Y.; Li, W.-J.; Che, P. Impact of reaction conditions on the structures of nickel(II) complexes based on 3-(4Carboxyphenyl)propionic acid. Z. Anorg. Allg. Chem. 2013, 639, 129-133. [CrossRef]

38. Wang, X.-L.; Qin, C.; Wang, E.-B. Polythreading of infinite 1D chains into different structural motifs: Two poly(pseudo-rotaxane) architectures constructed by concomitant coordinative and hydrogen bonds. Cryst. Growth Des. 2006, 6, 439-443. [CrossRef]

39. Sanram, S.; Boonmak, J.; Youngme, S. Ni(II)-metal-organic frameworks based on 1,4-phenylenedipropionic acid: Solvothermal syntheses, structures, and photocatalytic properties. Polyhedron 2016, 119, 151-159. [CrossRef]

40. $\mathrm{Hu}, \mathrm{M}$; Z Zhang, Q. Crystal structure of tetraaqua-(4,4'-bipyridine- $\left.\kappa^{2} N, N^{\prime}\right)$ nickel(II) 2,3-naphthalenedicarboxylate, $\left[\mathrm{Ni}\left(\mathrm{H}_{2} \mathrm{O}\right)_{4}\left(\mathrm{C}_{10} \mathrm{H}_{8} \mathrm{~N}_{2}\right)\right]\left[\mathrm{C}_{12} \mathrm{H}_{6} \mathrm{O}_{4}\right]$. Z. Kristallogr. New Cryst. Struct. 2010, 225, 155-156. [CrossRef]

41. Verma, S.K.; Singh, V.K. $\left[\mathrm{M}\left\{\kappa^{2} S, S-\mathrm{S}_{2} \mathrm{C} \text {-piperazine- } \mathrm{C}_{2} \mathrm{H}_{4} \mathrm{~N}=\mathrm{C}(\mathrm{R})\right\}_{n}\right]\{\mathrm{Co}(\mathrm{III}), \mathrm{Ni}(\mathrm{II}), \mathrm{Cu}(\mathrm{II})$ or $\mathrm{Zn}(\mathrm{II})\}$ complexes bearing pendant Schiff base moieties: Spectral characterization, fluorescence, cyclic voltammetric and TGA/DTA study. J. Coord. Chem. 2015, 68, 1072-1087. [CrossRef] 